\title{
KISAH DALAM ALQURĀN SEBAGAI MATERI DAKWAH
}

\section{Siti Musyahidah}

Dosen Tetap Fakultas Shari'ah dan Ekonomi Islam IAIN Palu

\section{Abstract}

One component of Islamic da'wah is the content that is essential for the effective implementation of da'wah. Without content, it is impossibe fo da'wah to be carried out effectively, and the goal will not be achieved. God gives a reference for the Muslim preacher to make the Qur'an as a source of da'wah materials, since in the Qur'ān there are a variety of science, stories (qasas) of the prophets and their people, așhäb al-kahf, and so forth. All of this can be used as da'wah materials. Moreover, the Qur'ann compiled the stories in certain categories, so it is so easily to take advantage, advice and values from it that can shape the quality of faith and piety.

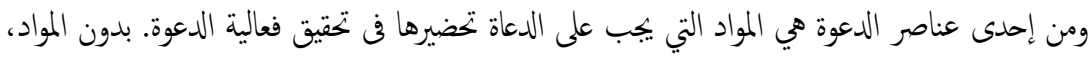

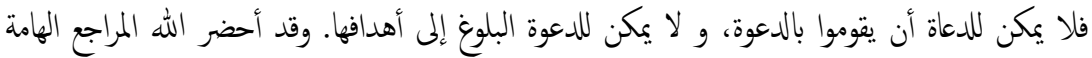

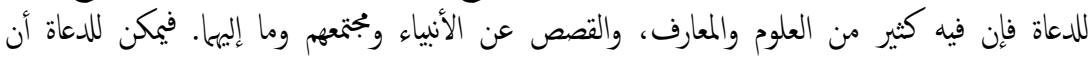

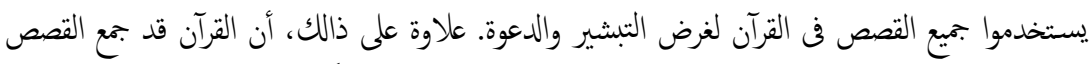

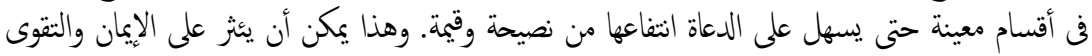

$$
\begin{aligned}
& \text { تأثيرا حسنا. }
\end{aligned}
$$

Kata Kunci: dakwah, materi, alqurān, kisah

\section{Pendahuluan}

Alqurān yang ada di hadapan kita merupakan kumpulan firman Allah yang diturunkan kepada Nabi Muhammad SAW melalui malaikat Jibril untuk disampaikan kepada umat manusia di dalamnya mengandung beberapa pembahasan, salah satu diantaranya oleh Hasbi Ash-Shiddieqy disebutkan kisah-kisah orang purbakala dan umat-umat dahulu. ${ }^{1}$ Kisah yang di dalam bahasa Indonesia lazim disebut cerita,

${ }^{1}$ Lihat, T.M. Hasbi Ash-Shiddieqy, Sejarah dan Pengantar Ilmu Aqurān/Tafsir, Jakarta: Bulan Bintang, 1990, h. 160. Salah satu sudut pembahasan ini, selanjutnya akan merupakan inti kajian yang akan ditelusuri dalam tulisan ini. 
memang merupakan sesuatu yang tidak terpisah dari kehidupan, bahkan dunia ini dalam sebutan lain dikenal sebagai "panggung sandiwara" kehidupan sebab di dalamnya kisah demi kisah, cerita demi cerita, di pentaskan-silih-berganti untuk menyampaikan pesan-yang benar-benar terjadi dan/hayalan-dari satu pihak kepada pihak lain. Di dalam persoalan kisah ini, dapat ditemukan "kisah faktawi" yang memang benar-benar terjadi dalam realita sesuai dengan fakta-fakta yang ada, dan ditemukan pula "kisah hayali" yang ada di dalamnya disajikan rekaan fakta-fakta yang dihayalkan oleh pengarangnya sebagai sesuatu yang menarik seakan-akan memang benar fakta-fakta itu terjadi demikian.

Kisah yang tertuang dalam Alqurān, yang berasal dari wahyu/firman Allah SWT Yang Maha Benar, sudah tentu berbeda dengan kisah di luar Alqurān. Kalau kisah dalam Alqurān mengingat ia diperoleh dari sumber Yang Maha Benar yang dikisahkan untuk menginformasikan kebenaran petunjuk wahyu ${ }^{2}$ maka dapat dipastikan bahwa seluruh kisahnya hanya berupa "kisah-kisah faktawi" yang benar-benar terjadi demikian sesuai dengan fakta-fakta yang ada.

Sedang kisah di luarnya, yang oleh Umar Kayam dilukiskan sebagai mencoba memahami kehidupan dengan suatu interpretasi lewat penciptaan dunia alternative (dunia rekaan) ${ }^{3}$ yang sering disajikan dalam bentuk cerpen, cergam, ataupun berbentuk legenda atau mitos yang dituturkan dari lisan ke lisan dengan dihubungkan kepada dewa atau sesuatu yang suci, kisah-kisah semacam ini merupakan karya rekaan yang diperkokoh dengan fakta-fakta yang berfungsi untuk meyakinkan pencitraan dari latar dunia rekaan itu sehingga kisah-kisah

'Lihat, misalnya Q.S. Alisra' (17), 9,bahwa sesungguhnya Alqurān ini memberikan petunjuk kepada jalan yang lebih lurus. Sehingga kisah-kisah dalam Alqurān memang hanya berisi cerita yang benar-benar terjadi demikian, sesuai dengan fakta-kejadiannya.

${ }^{3}$ Dr. Umar Kayan, “Menilai Karya Tulisan Ilmiah' dalam buku Metode dan Teknik Penulisan Ilmiah. Surakarta: Fakultas Ilmu Sosial dan Politik Universitas Sebelas Maret 1984, h. 43. 


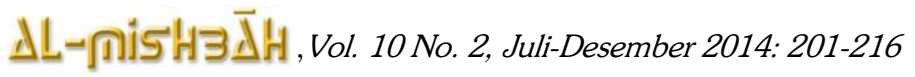

demikian tergolong di dalam "kisah hayali" karena status fakta hanya untuk menyakinkan pencitraan.

Tulisan sederhana ini akan memaparkan kisah yang tertuang di dalam Alqurān yang kemudian dapat digunakan sebagai materi dakwah.

\section{Pembahasan}

\section{A. Pengertian Kisah}

Kisah merupakan suatu perkara yang dipandang penting di dalam Islam. Tidak kurang dari 26 tempat di dalam Alqurān menyebutkan mengenai kisah ini dalam berbagai redaksinya ${ }^{4}$. Bahkan surat ke-28 yang di dalamnya memuat secara lebih lengkap kisah Nabi Musa As diberi nama khusus dengan Surah Alqașaș (cerita-cerita) ${ }^{5}$. Sebelum secara lebih khusus dibahas mengenai kisah ini, perhatian difokuskan untuk menjawab apa sebenarnya kisah itu.

Istilah "kisah" berasal dari bahasa Arab قصص yakni mașdar (verbal noun). Ia diambil dari kata kerja قصص yang berakar kata dengan huruf ق (qaff)dan ص (sad). Akar kata ini mempunyai arti pokok "dasar yang benar yang menunjukkan atas pengikutan (penelusuran) sesuatu". Dari kontek ini dikatakan (aku mengikuti jejak sesuatu) apabila engkau berjauhan dengannya ${ }^{6}$. Dari kontek itu jugalah pengambilan kata qisas dalam melukai, yang demikian itu sebab qasas diberlakukan sebagaimana melakukan perbuatan itu pertama kali, sehingga seolaholah mengikuti jejak seuatu. Dari istilah qāsas (cerita) dan qasas (cerita-

4 Lihat, Muhammad Fu'ad Abd al-Baqi, Al-Mu'jām al-Muhfaras Li-Alfazh Alqurān al-karim, /t.t./: Dar al-Fikr, 1986 M/1406 H, h.

${ }^{5}$ Dinamakan dengan "Alqașaṣ" sebab pada ayat 25 surat ini terdapat kata alqashash yang berarti cerita. Dalam surat ini terdapat kisah seperti: kekejaman Fir'aun dan pertolongan serta karunia Allah kepada Bani Israil; Musa As dilemparkan ke sungai Nil; seorang Qibthi terbunuh oleh Musa As; Musa di Madyan; Musa diperintah Allah menyeru Fir'aun di bukit Thur, kisah Qarun.

${ }^{6}$ Lihat, misalnya Abi Alhusain Ahmad Ibn Faris bin Zakariyya (selanjtnya di sebut Ibnu Faris), Mu'jam Maqayis Allughah, Mesir: Musthafa al-Babi Alhalabi Wa Awladuh, $1792 \mathrm{H} / 1972 \mathrm{M}$. 
cerita), kesemuanya itu merupakan hal yang diikutsertai (ditelusuri) dan disebutkan? .

Apabila kisah ini dikaitkan dengan Alqurān dapat diperoleh pengertian bahwa kisah Alqurān itu adalah suatu berita/cerita yang dapat diikuti/ditelusuri jejaknya yang menyampaikan kejadian umatumat terdahulu, nabi-nabi/rasul-rasul, serta kejadian-kejadian lain sebagai benar-benar terjadi demikian.

\section{B. Materi Dakwah}

Sebelum penulis menguraikan tentang materi dakwah, terlebih dahulu dijelaskan tentang apa yang dimaksud dengan dakwah. Secara etimologi, dakwah berasal dari kata دعوة يدعو- دع "mang berarti "mengajak", "memanggil", "mengundang", "mendorong". Secara terminologi, Toha Yahya Umar mengatakan bahwa dakwah menurut Islam adalah; "Mengajak manusia dengan cara bijaksana kepada jalan yang benar sesuai perintah Tuhan, untuk kemaslahatan dan kebahagian mereka di dunia dan di akhirat'. ${ }^{8}$

Menurut Syekh Ali Mahfuz, Dakwah adalah "Mendorong manusia atas kebaikan dan mencegah dari kemungkaran guna mendapatkan kebahagiaan hidup di dunia dan di akhirat". "(Dari kondisi) Positif kekondisi yang lebih positif . ${ }^{9}$

Sedangkan materi dakwah adalah bahan, isi, atau pesan dakwah. Materi dakwah dapat berupa gagasan, teori, dasar pengetahuan, ilmu pengetahuan, bahkan kisah-kisah yang mengandung nilai-nilai pendidikan yang membentuk pengetahuan dan keyakinan dan karakter seseorang dan dari situ akan membentuk sikap dan tindakan atau perilakunya. Maka kisah-kisah dalam Alqurān dapat menjadi salah

${ }^{7}$ Ibid.

${ }^{8}$ Toha Yahya Umar, Ilmu Dakwah, (Cet. IV; Jakarta: Widjaya, 1985), h. 1

${ }^{9}$ Syekh Ali Mahfuz, Hidāyah Murshidin ilā Turuqi an-Nậs wa Alkhatabah, (Beirut: Dār al-Ma'ārif, tth), h. 1 


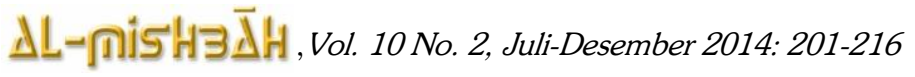

satu bentuk materi dakwah yang memberi banyak nilai, pelajaran dan menambah keyakinan bagi umat Islam.

\section{Kisah Dalam Alqurān Sebagai Materi Dakwah}

Sebagaimana diketahui, Alqurān mengandung berbagai macam ilmu didalamnya, salah satu diantaranya adalah kisah atau qașașul qurān. Kisah-kisah tersebut jika ditelusuri dari keterangan Alqurān dapat diklasifikasikan menjadi tiga macam, yaitu:

Pertama: Kisah Nabi-nabi (Qașaș, Alanbiya). Salah satu kisah macam ini, misalnya kisah yang terdapat dalam surah As-șâffāt yang selain memperingatkan orang musyrik Arab Mekkah kepada 'azab Allah yang sangat pedih yang akan dirasakannya nanti di neraka, dalam surat ini terdapat kisah beberapa Nabi, umpamanya:

1. Nabi Nuh As: yang dikabulkan do'anya oleh Allah. Sehingga Nabi Nuh dan keluarganya diselamatkan dari bencana besar, dan ditenggelamkanlah orang-orang yang mendustakannya (Q.S. 37:7582). ${ }^{10}$

2. Nabi Ibrahim As: telah menghancurkan berhala-berhala kaumnya. Sehingga kaum itu bermaksud untuk membunuhnya. Oleh mereka didirikanlah bangunan untuk membakar Nabi Ibrahim As dengan bara api yang menjilat-jilat. Namun Allah SWT menyelamatkannya, dengan menjadikan api dingin dan menyelamatkan bagi Nabi Ibrahim (Q.S. 37:83-99). ${ }^{11}$

3. Nabi Ibrahim As dan Kibas. Nabi Ibrahim yang menginginkan putera yang shaleh, sebegitu besar puteranya oleh Allah diperintahkan untuk disembelih sebagai kurban. Akhirnya, sembelihan itu oleh Allah diganti dengan kibas (Q.S. 37:100-111). ${ }^{12}$

${ }^{10}$ Kementerian Agama RI, Alqurān dan Terjemahnya, (Bandung: Fokus Media, 2010), h. 448

\footnotetext{
${ }^{11}$ Ibid., h. 449

12 Ibid.
} 
4. Nabi Musa As dan Nabi Harun As: telah dipilih Allah SWT untuk menyampaikan risalah-Nya kepada Fir'aun Raja Mesir dan kepada keduanya diberinya kitab Taurat. Allah telah menyelamatkan keduanya dari bencana besar-pengejaran Fir'aun dan pasukannya, yang mereka akhirnya mati tenggelam di laut (Q.S. 37:114-122). ${ }^{13}$

5. Nabi Ilyas As: telah mengingatkan kaumnya agar tidak menyembah Ba'al (nama salah satu berhala orang Punicia) dan hanya menyembah Allah, Pemelihara mereka. Namun, mereka mendustakannya (Q.S. 37:123-132). ${ }^{14}$

6. Nabi Luth As dan Keluarganya: telah diselamatkan oleh Allah SWT (kecuali isterinya) dari hujan batu dan gempa bumi yang hebat, yang menimpa kaumnya yang "homosexual" sehingga mereka binasa dan terbaliklah kotanya (Sadom) dalam keadaan hancur (Q.S. 37:133138). ${ }^{15}$

7. Nabi Yunus As: seorang Rasul yang merasa tidak mampu menghadapi kaum yang mendustainya lalu lari meninggalkan mereka, dengan menaiki perahu yang bermuatan penuh. Hanya malang, di tengah perjalanan perahu itu terumbang-ambing angin dan ombak. Sehingga untuk menyelamatkan perahu dan penumpang terpaksa mengurangi penumpang dengan melalui pengundian, siapa yang kalah dilempar ke laut, dan Nabi Yunus termasuk yang kalah ini. Lalu beliau ditelan ikan besar dalam keadaan tercela itu. Akhirnya Allah SWT mengabulkan doa'nya, sehingga Nabi Yunus As bisa keluar dari perut ikan besar dan terlempar ke tepi pantai (sekampiun) dalam keadaan sakit. Setelah sembuh dari sakitnya, beliau kembali mengajak kaumnya untuk menyembah Allah SWT. Ajakannya dikabulkan, dan kaum yang berjumlah \pm 100.000 orang beriman seluruhnya (Q.S. 37:139-148). ${ }^{16}$
${ }^{13}$ Ibid., h. 450
${ }^{14}$ Ibid., h. 450-451
${ }^{15}$ Ibid.
${ }^{16}$ Ibid. 


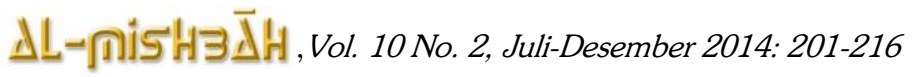

Kisah-kisah para Nabi tersebut di dalam Surat Al-Ṣaffāt dikemukakan secara singkat, yang dimaksudkan untuk mengingatkan orang-orang musyrik Mekkah tentang kemungkinan mereka menerima azab Allah sebagaimana dialami oleh umat-umat terdahulu yang mendustakan Nabi-nabinya.

Selain kisah-kisah tersebut, kisah-kisah yang termasuk macam atau jenis kisah yang pertama ini bila ditelusuri di dalam Alqurān dijumpai juga kisah-kisah yang mengandung dakwah Nabi kepada kaumnya, berisi mu'jizat yang memperkokoh risalahnya, menentang orang-orang yang ingkar, perjalanan dakwah dan perkembangannya, serta balasan bagi orang mu'min dan orang-orang yang ingkar, yang kesemuanya ini karena keterbatasan ruang tidak disinggung di bagian ini.

Kedua: Kisah-kisah yang berkaitan dengan peristiwa-peristiwa yang terjadi pada zamann Rasul SAW. Seperti: peperangan Badr dan Uhud sebagaimana disebutkan dalam Surat Ali' Imrān ayat 121-129, peperangan Hunain dan Tabuk yang disebutkan dalam Surat Attaubah ayat 38-43, peperangan Ahzab seperti disebutkan dalam surat Alahzab ayat 9-20, peristiwa Isra' Nabi Muhammad SAW yang disebutkan dalam Surat Alisra' ayat 1 , dan lain-lainnya.

Ketiga: Kisah-kisah Qurāni yang berkaitan dengan peristiwa peristiwa yang telah terjadi dan orang-orang yang tidak dapat dipastikan era keNabiannya. Termasuk di dalam kisah macam ketiga ini, misalnya: kisah orang-orang yang pergi dari kampong halamannya dalam jumlah ribuan (hanya) karena takut mati yang terdapat di dalam Surat Albaqarah ayat 243, yang mana kata "mati" di sini ditafsirkan sebagai mati sebenarnya oleh sebagian ulama dan sebagai mati semangat oleh sebagian lainnya: kisah Talut dan Jalut yang terdapat di dalam Surat AlBaqarah 246-252 yang di dalam peperangan keduanya maka Talut yang di dalamnya terdapat Nabi Daud dapat mengalahkan tentara Jalut dengan izin Allah sehingga Allah memberikan kepada Daud pemerintahan dan hikmah (kenabian dan kitab Zabur). 
Kisah Ashāb Alkahf yang tertuang dalam Surat Alkahf ayat 9-26, yang didalamnya mengisahkan tiga babak cerita:

1) dengan beberapa pemuda yang sebenarnya tertidur di sebuah gua (ditidurkan Allah) dalam waktu cukup panjang (309 tahun), yang tidak biasa dialami oleh manusia biasa, dengan maksud untuk menyelamatkan agama dan jiwa mereka dari kekejaman Raja dan rakyat yang menyembah berhala.

2) Mereka terbangun dan mereka segar dan mempunyai semangat baru pada diri mereka. Mereka lalu membuka matanya dan berpandangan satu sama lain dengan perasaan heran dan ganjil, sebab dirasakannya sebagai baru saja bangun dari tidur yang cukup lama yang sebenarnya mereka sendiri tidak mengetahui berapa lamanya telah tertidur nyenyak. Sehingga diantara mereka saling-bertanya tentang lama-tidur mereka; ada yang mengira tidurnya tidak lebih dari sehari atau setengah hari. Dan pada akhirnya, mereka menyerahkan persoalan mereka kepada Allah, sebab pemuda-pemuda itu memang orang-orang yang beriman kepada Allah yang selalu menyerahkan persoalan yang ada kepada Allah (Q.S. Al-kahf:19).

3) salah seorang diantara mereka disuruh oleh kawan-kawannya agar pergi ke kota dengan membawa uang perak yang masih ada padanya untuk membeli makanan yang enak, sebab mereka sangat lapar setelah tidur yang sangat panjang itu. Dalam pencarian membeli makanan itu, kawan-kawannya berpesan agar ia bersikap hati-hati dan menjauhi orang-orang musyrik di kota itu. Sebab, kalau saja mereka mengenalnya dan mengetahui tempat persembunyiannya, pastilah pemuda-pemuda itu akan dibunuh-rajam atau dipaksa meninggalkan agama mereka (monotheis) itu dan akhirnya masuk menjadi polytheis (Q.S. Alkahf 19-20). Demikian tiga babak cerita Ashhab al-kahf ini, selain ini terdapat juga kisah Zulqarnain dengan Ya'juj dan Ma'juj sebagaimana tertuang dalam Surat Alkahf 83-101, dimana Zulqarnain diberi kekuasaan di muka bumi oleh Allah dengan 
diberinya perangkat "jalan untuk mencapai segala sesuatu" di suatu ketika berhadapan dengan Ya'juj dan Ma'juj (ayat 94) yang suka membuat kerusakan di muka bumi; Akhirnya kisah-kisah Qarun sebagaimana tersebut dalam Surat Alqașas ayat 76-82, kisah Maryam dalam Surah Maryam ayat 16-22, kisah Așsab Alkhudūd dalam Surat Alburūj 4 dan seterusnya. yang telah dibinasakan Allah, dan lain-lain termasuk di dalam macam kisah kelompok ketiga ini.

Demikian tiga macam kisah yang tertuang di dalam Alqurān. Dari paparan kisah-kisah di atas dapat diketahui bahwa kisah-kisah Alqurān itu tidak menceritakan kejadian dan peristiwa sebagaimana layaknya cerita-cerita/sejarah pada umumnya yang kronologis, serta tidak pula memaparkan kisah-kisahnya secara panjang lebar. Kenyataan demikian sudah tentu bahwa kisah-kisah Alqurān itu disampaikan kepada umat manusia karena dikandung tujuan tertentu.

Selanjutnya mengkaji tujuan kisah Alqurān, berarti mempelajari apa yang menjadi maksud Ilahi dalam menyampaikan peristiwa/ kejadian bagi umat manusia, baik yang menyangkut perorangan maupun umat. Menurut Muhammad Baha'i Salim tujuan Ilahi menyampaikan kisah dalam Alqurān ${ }^{17}$ adalah sebagai pengajaran dan peringatan, serta sebagai tempat persandaran Rasul.

1. Sebagai pelajaran dan peringatan adalah tujuan pertama dari penyampaian kisah di dalam Alqurān. Kisah Alqurān merupakan pelajaran bagi manusia dengan cara-cara penyampaian yang lebih baik dan merupakan peringatan bagi manusia yang dapat mengambil pelajaran dari kejadian-kejadian yang telah lalu dan terlihat di dunia ini serta yang ada pada diri manusia sesuai dengan pemberian Allah SWT, sehingga dengan itu bertambahlah rasa ketakwaan, keimanan, serta terpenuhi di dalamnya kebaikan dari segala unsur kebaikan bagi manusia seluruhnya. Untuk itu Allah SWT berfirman dalam Surah Ali

${ }^{17}$ Muhammad Baha'I Salim, Alqurān al-Karim wa Suluk al-Insāni, Kairo: /t.p./, 1987, h.h. 337-340 
'Imrān 138: "Alqurān ini adalah penerangan bagi seluruh manusia, dan petunjuk serta pelajaran bagi orang-orang yang bertakwa" ${ }^{18}$

Dalam Surah Ali 'Imran ayat 137 Allah SWT juga memfirmankan; "Sesungguhnya telah berlalu sebelum kamu sunnahsunnah Allah (berupa bencana dan malapetaka); karena itu berjalanlah kamu di muka bumi dan perhatikanlah bagaimana akibat orang-orang yang mendustakan (rasul-rasul)". ${ }^{19}$

Allah SWT berfirman tentang Nabi Musa dalam Surah Maryam (19): 51: "Dan ceritakanlah (hai Muhammad kepada mereka), kisah Musa di dalam Al-kitab (Alqurān) ini. Sesungguhnya ia adalah seorang yang dipilih dan seorang Rasul dan Nabi' . ${ }^{20}$

Di dalam Surah Maryam (19): 54 difirmankan tentang Nabi Isma'il: "Dan ceritakanlah (hai Muhammad kepada mereka) kisah Isma'il (yang) tersebut didalam Alqurān. Sesungguhnya ia adalah seorang yang benar janjinya, dan dia adalah seorang Rasul dan Nabi'. ${ }^{21}$ Juga, mengenai Nabi 'Isa difirmankan Allah dalam Surah Maryam (19): 34; "Itulah 'Isa putera Maryam, yang mengatakan perkataan yang benar, yang mereka berbantah-bantahan tentang kebenarannya". ${ }^{22}$

Demikian juga, Allah SWT menjelaskan kepada kita tentang fadhilah (keutamaan) yan diberikan kepada hamba-Nya, kemudian dia memuji dan mensyukuri, sehingga Allah menambahi mereka iman dan takwa. Difirmankan mengenai Nabi Dawud dan Nabi Sulaiman dalam S. Annaml (27): 15 sebagai berikut: "Dan sesungguhnya kami telah memberi ilmu kepada Dawud dan Sulaiman dan keduanya mengucapkan: "Segala puji bagi Allah yang melebihkan kami dari kebanyakan hamba-hambanya yang beriman". ${ }^{23}$

\footnotetext{
${ }^{18}$ Kementerian Agama, Alqurān...., h. 67

${ }^{19}$ Ibid.

${ }^{20}$ Ibid., h. 369

21 Ibid.

${ }^{22}$ Ibid., h. 307

${ }^{23}$ Ibid., 378
} 


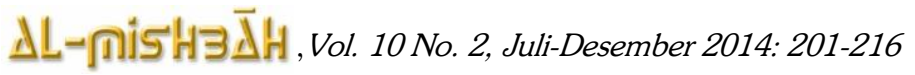

Dalam Surat yang sama ayat 16, Allah SWT memfirmankan pula:

"Dan Sulaiman telah mewarisi Dawud (kenabian, kerajaan, ilmu) dan dia berkata: "Hai manusia kami telah diberi pengertian tentang ucapan burung dan kami diberi segala sesuatu. Sesungguhnya (semua) ini benar-benar suatu karunia yang nyata". ${ }^{24}$

Jauh berbeda dari kedua teladan shaleh dari para Nabi dan Rasul Allah dan antara orang-orang kufur yang ingkar atas nikmat dan keutamaan Allah, orang-orang yang melampaui batas dan takabbur dengan apa-apa yang dikaruniakan Allah sebagai ganti dari pujian dan syukurnya kepada Allah SWT, seperti kisah qarun yang semakin kufur, dalam Surah Alqașaṣ (28):76:

"Sesungguhnya Qarun adalah termasuk kaum Musa (anak paman S. Musa), maka ia berlaku aniaya terhadap mereka, dan Kami telah menganugerahkan kepadanya perbendaharaan harta yang kunci-kuncinya sungguh berat dipikul oleh sejumlah orang yang kuat-kuat. (Ingatlah) ketika kaumnya berkata kepadanya: "Janganlah kamu terlalu bangga; sesungguhnya Allah tidak menyukai orang-orang yang terlalu membanggakan diri" ${ }^{25}$

Pernyataan kaumnya itu, dijawab Qarun dalam ayat (78):

"Qarun berkata: "Sesungguhnya aku hanya diberi harta itu, karena ilmu yang ada padaku". Dan apakah ia tidak mengetahui, bahwasanya Allah sungguh telah membinasakan umat-umat sebelumnya yang lebih kuat dari padanya, dan lebih banyak mengumpulkan harta? Dan tidaklah perlu di Tanya kepada orangorang yang berdosa itu, tentang dosa-dosa mereka". ${ }^{26}$

Sebagai pungkasannya, Allah SWT menegaskan dalam ayat ke81 yang berbunyi:

"Maka kami benamkanlah Qarun beserta rumahnya ke dalam bumi. Maka tidak ada baginya suatu golongan pun yang

\footnotetext{
${ }^{24}$ Ibid.

${ }^{25}$ Ibid., h. 394

${ }^{26}$ Ibid., h. 395
} 
menolongnya terhadap azab Allah. Dan tiadalah dia termasuk orang-orang (yang dapat) membela (dirinya)" ${ }^{27}$

Demikian sebagian ayat-ayat Allah di dalam Alqurān yang menjelaskan tentang pelajaran dan peringatan kepada hambanya, untuk menunjukkan ke jalan yang lurus, sebagai tujuan kisah Alqurān yang pertama.

2. Sebagai tempat persandaran Rasul Allah. Selain untuk memberikan pelajaran dan peringatan kepada umat manusia, kisah Alqurān itu dilihat dari sudut "pembawa risalah" adalah untuk dijadikan tempat bersandar Rasul Allah, atau sebagai rujukan bagi Rasul dalam menyampaikan risalahnya berhadapan dengan kaum yang menentangnya. Seperti di ketika Rasul Allah SAW berhadapan dengan orang-orang kafir dan orang-orang yang mendustakan seraya mengajukan pertanyaan dalam Surat Alkahf (18) ayat 83-84:

"Neraka bertanya kepadamu (Muhammad) tentang Zulqarnain. Katakanlah: "Aku akan bacakan kepadamu cerita tentangnya". Sesungguhnya Kami telah member kekuasaan kepadanya di (muka) bumi, dan Kami telah memberikan kepadanya jalan (untuk mencapai) segala sesuatu)" ${ }^{28}$

Dan telah dipaparkan kepada kita oleh Alqurān suatu contoh kejadian sepanjang ke'arifan Rasul SAW yang lapang dadanya berupa kemampuan untuk bertindak sabar di hadapan orang-orang yang menentangnya untuk bertindak sabar di hadapan orang-orang yang menentangnya, yang menentang serta menghina kebenaran. Difirmankan dalam Surah Attaubah (9): 64-65:

"Orang-orang yang munafiq itu takut akan diturunkan terhadap mereka sesuatu surat yang menerangkan apa yang tersembunyi dalam hati mereka. Katakanlah kepada mereka: "Teruskanlah ejekan-ejekanmu (terhadap Allah dan Rasul-Nya)". Sesungguhnya Allah menyatakan apa yang kami takuti itu. Dan jika kamu tanyakan kepada mereka (tentang apa yang mereka lakukan itu), tentulah mereka akan menjawab: "Sesungguhnya kami hanyalah

\footnotetext{
27 Ibid.

${ }^{28}$ Ibid., h. 303
} 


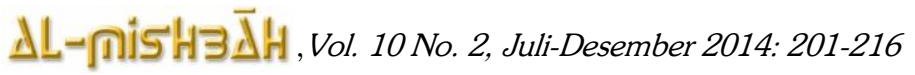

bersenda-gurau dan bermain-main saja". Katakanlah: "Apakah dengan Allah, ayat-ayat-Nya, dan Rasul-Nya kamu selalu berolokolok?"). ${ }^{29}$

Allah SWT juga mengukuhkan dan memberikan suatu sandaran kepada Rasul-Nya dengan ilmu yang bisa mengetuk pintu hati tiap-tiap orang yang takabbur dari $A h l$ Alkitäb, dengan menceritakan kepadanya apa saja yang dikerjakan mereka serta menyingkap apa saja yang tersembunyi di dadanya, sebagai disebut dalam S. Al a'rāf (7):163:

"Dan tanyakanlah kepada Bani Israil tentang Negeri (kota Eilah, terletak diantara kota Madyan dan Bukit Thur di pantai Laut Merah) yang terletak di dekat laut ketika mereka melanggar aturan pada hari Sabtu (yang mestinya tidak boleh bekerja, melainkan khusus untuk beribadat), di waktu dating kepada mereka ikan-ikan (yang berada disekitar) mereka terapung-apung di permukaan air, dan di hari-hari yang bukan Sabtu, ikan-ikan itu tidak dating kepada mereka. Demikianlah Kami mencoba mereka disebabkan mereka berlaku fasik". ${ }^{30}$

Demikian tujuan kisah Alqurān didalam menyampaikan beritaberitanya kepada umat manusia, baik yang ditujukan kepada kalangan khusus maupun kelompok ummat dan khususnya kepada kerisalahan Nabi/Rasul untuk menjadi sandaran atau pun rujukan dalam menghadapi kaum yang menentangnya. Keseluruhan kisah dalam Alqurān itu sesuai dengan kebenaran isi firman-firman Allah SWT sendiri tidaklah lain kecuali hanya menyampaikan kebenaran demi kebenaran dari Allah SWT. ${ }^{31}$

\section{Pengulangan Kisah Dan Hikmahnya}

Di dalam Alqurān kisah-kisah ditemukan penuturannya secara berulang-ulang di dalam beberapa surat. Sebuah kisah, bisa disebutkan berkali-kali, dalam bentuk yang berbeda-beda, kadang-kadang pendek

\footnotetext{
${ }^{29}$ Ibid., h. 197

${ }^{30}$ Ibid., h. 171

${ }^{31}$ Lihat, misalnya, Q.S. Al-Baqarah (2): 147, bahwa kebenaran itu adalah dari Tuhanmu, sebab itu jangan sekali-kali kamu termasuk orang-orang yang ragu.
} 
dan kadang-kadang panjang. Keseluruhan kisah itu tentu mempunyai hikmah-hikmah sebagai berikut ini; ${ }^{32}$

1) Menandaskan kebalaghahan Alqurān dalam bentuk yang paling tinggi. Di antara keistimewaan-keistimewaan balaghah itu, ia dapat menerangkan satu makna dalam berbagai-bagai susunan. Dan pada tiap-tiap tempat disebutkan perkataan yang berbeda-beda dari yang telah disebutkan. Dengan demikian, akan terasa "sedap" Alqurān itu didengar dan dibacanya.

2) Menampakkan kekuatan I'jaz. Menyebutkan suatu makna dalam berbagai-bagai bentuk struktur perkataan yang salah satunya tidak dapat ditentang oleh sastrawan-sastrawan Arab, memperjelas bahwa Alqurān itu benar-benar berasal dari Allah.

3) Memberikan perhatian penuh kepada kisah itu. Mengulang-ulangi penyebutannya adalah termasuk salah satu dari jalan-jalan ta'kid dan salah satu dari tanda-tanda besarnya perhatian, seperti keadaan kisah Musa dan Fir'aun.

4) Karena berbedanya tujuan menyebabkan disebutnya kisah itu. Di suatu tempat kisah itu diterangkan sebagian disebabkan karena hanya itu saja yang diperlukan, dan di tempat-tempat yang lain di sebutkan secara lebih sempurna disebabkan karena yang demikianlah yang dikehendaki keadaan.

Demikian kisah Alqurān itu disebutkan secara berulang-ulang di dalam beberapa surat beserta hikmahnya yang menunjukkan betapa luhurnya kisah-kisah itu menyampaikan beritanya untuk kepentingan umat manusia, sebagai pelajaran dan peringatan di samping sebagai bukti bagaimana Rasul menjadikannya sebagai rujukan di ketika menghadapi umat yang menantangnya.

\footnotetext{
${ }^{32}$ Lihat, Hasbi Ash-Shiddieqy, Ilmu-ilmu Alqurān, Jakarta: Bulan Bintang, h.
} 189. 


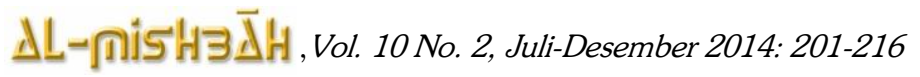

\section{Penutup}

Sebagai bagian penutup dari tulisan ini dikemukakan kesimpulan sebagai berikut ini.

Kisah Alqurān yang merupakan suatu berita atau cerita yang dapat telusuri jejaknya yang menyampaikan kejadian umat terdahulu, para Nabi dan Rasul, serta kejadian-kejadian lain yang benar-benar terjadi adalah bagian dari kumpulan firman Allah yang disampaikan di dalam kehidupan umat manusia dengan tujuan sebagai pengajaran, peringatan, dan persandaran Rasul dalam menyampaikan risalah di hadapan umatnya.

Di dalam Alqurān yang kisah-kisahnya menyampaikan essensi kebenaran demi kebenaran firman Allah SWT itu yang dimaksudkan untuk mencapai suatu tujuan yang telah digariskan, tidak ditemukan adanya cerita-cerita, termasuk mitos, dimana fakta telah diberi pencitraan melalui imajinasi pengarangnya. Sehingga, pada kisah-kisah Alqurān ditemukan adanya pergulangan dalam beberapa surat yang berbeda dengan cerita-cerita umumnya dan hal ini merupakan hikmah Alqurān yang membedakan dari lainnya.

\section{Daftar Pustaka}

Abd al-Baqi, Muhammad Fu'ad, Al-Mu'jām al-Muhfaras Li-Alfaz Alqurān al-Karim, /t.t./: Dar al-Fikr, 1986 M/1406 H.

Ash-Shiddieqy, T.M. Hasbi, Sejarah dan Pengantar Ilmu Alqurān/Tafsir, Jakarta: Bulan Bintang, 1990.

Ash-Shiddieqy, T.M. Hasbi, Ilmu-ilmu Alqurān, Jakarta: Bulan Bintang.

Asy-Syirbashi, Ahmad, Sejarah Tafsir Qurān, disunting oleh Amak Baljun, Jakarta: Pustaka Firdaus, 1985.

Ibn Faris bin Zakariyya, Abi al-Husain Ahmad, Mu'jām Maqayis alLughah, Mesir: Mustafa al-Bābi al-Halabi Wa Awlāduh, 1792 $\mathrm{H} / 1972 \mathrm{M}$.

Kayan, Umar, Metode dan Teknik Penulisan Ilmiah. Surakarta: Fakultas Ilmu Sosial dan Politik Universitas Sebelas Maret. 1984, 
Musyahidah, Kisah Dalam Alqurān Sebagai Materi Dakwah

Kementerian Agama RI, Alqurān dan Terjemahnya, Bandung: Fokus Media, 2010.

Mahfuz, Syekh Ali, Hidāyah Murshidin ilā Turuqi an-Nās wa Alkhatabah, Beirut: Dār al-Ma'ārif, tth.

Salim, Muhammad Baha'i, Alqurān al-Karim Wa Suluk al-Insani, Kairo: /t.p./, 1987.

Yahya Umar, Toha, Ilmu Dakwah, Cet. IV; Jakarta: Widjaya, 1985. 